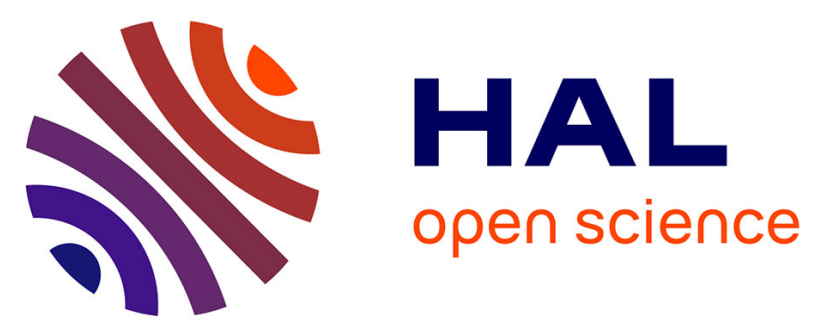

\title{
Vehicular Emission Ratios of VOCs in a Megacity Impacted by Extensive Ethanol Use: Results of Ambient Measurements in São Paulo, Brazil
}

Joel Brito, Florian Wurm, Ana Maria Yáñez-Serrano, João Vicente de Assunção, José Marcus Godoy, Paulo Artaxo

\section{To cite this version:}

Joel Brito, Florian Wurm, Ana Maria Yáñez-Serrano, João Vicente de Assunção, José Marcus Godoy, et al.. Vehicular Emission Ratios of VOCs in a Megacity Impacted by Extensive Ethanol Use: Results of Ambient Measurements in São Paulo, Brazil. Environmental Science and Technology, 2015, 49 (19), pp.11381 - 11387. 10.1021/acs.est.5b03281 . hal-01836106

\section{HAL Id: hal-01836106 \\ https://hal.uca.fr/hal-01836106}

Submitted on 5 May 2021

HAL is a multi-disciplinary open access archive for the deposit and dissemination of scientific research documents, whether they are published or not. The documents may come from teaching and research institutions in France or abroad, or from public or private research centers.
L'archive ouverte pluridisciplinaire HAL, est destinée au dépôt et à la diffusion de documents scientifiques de niveau recherche, publiés ou non, émanant des établissements d'enseignement et de recherche français ou étrangers, des laboratoires publics ou privés.

\section{(1) (1) $\$$}

Distributed under a Creative Commons Attribution - NonCommercial - NoDerivatives 44.0 


\title{
Vehicular Emission Ratios of VOCs in a Megacity Impacted by Extensive Ethanol Use: Results of Ambient Measurements in São Paulo, Brazil
}

\author{
Joel Brito, ${ }^{* \dagger}$ Florian Wurm, ${ }^{\dagger}$ Ana Maria Yáñez-Serrano, ${ }^{\ddagger}, \S$ João Vicente de Assunção," \\ José Marcus Godoy, ${ }^{\perp}$ and Paulo Artaxo \\ ${ }^{\dagger}$ Physics Institute, University of São Paulo, São Paulo, Brazil \\ ${ }^{\ddagger}$ National Institute of Research in Amazonia, Manaus, Amazonia Brazil \\ ${ }^{\S}$ Biogeochemistry Department, Max Planck Institute for Chemistry, Mainz, Germany \\ "School of Public Health, University of São Paulo, São Paulo, Brazil \\ ${ }^{\perp}$ Chemistry Department, Pontifical Catholic University of Rio de Janeiro, Rio de Janeiro, Brazil
}

\section{Supporting Information}

\begin{abstract}
The São Paulo Metropolitan Area (SPMA) is a megacity with 20 million people and over 8 million vehicles. Over the past decade a large increase in biofuel usage, more notably ethanol by light-duty vehicles, has made Brazil, and in particular São Paulo, a unique case worldwide. This study presents the first assessment of emission ratios of a selected group of volatile organic compounds (VOCs) relative to carbon monoxide (CO) under ambient conditions. The VOCs studied here include aromatics such as benzene (1.03 pptv/ ppbv CO), toluene (3.10 pptv/ppbv CO) and Oxygenated VOCs such as methanol (5.39 pptv/ppbv CO), acetaldehyde (3.93 pptv/ppbv CO), acetone (3.59 pptv/ppbv CO), methyl ethyl ketone (1.42 pptv/ppbv CO), and others. Despite the specificity of the fuel composition, emission ratios were in surprisingly close agreement with other megacities in Europe or in North America. Such results include species whose emission factors have been previously reported to decline (e.g., benzene) or increase (e.g., acetaldehyde) with ethanol usage. Furthermore, diurnal profiles and temperature analysis aid separating the primary anthropogenic, secondary or biogenic components of the species studied here. This study shows that a significant fraction of ethanol in gasoline blends does not result in a well-defined trend in VOC emission profile and certainly motivates further studies.
\end{abstract}

\section{INTRODUCTION}

Emissions in megacities in both the developed and developing parts of the world are strongly impacted by the transportation sector. The São Paulo Metropolitan Area (SPMA), located in the southeast of Brazil, has a population of nearly 20 million people and 8 million vehicles, many of which are fueled by a considerable amount of ethanol. ${ }^{1}$ Such a fleet is considered a unique case of large-scale biofuel usage worldwide. Current inventories attribute over $80 \%$ of hydrocarbons emissions within the SPMA to vehicular sources. ${ }^{2}$ Despite the large impact on human health and atmospheric chemistry dynamics, many uncertainties are found in terms of gas and particulate matter emissions from vehicles and their corresponding atmospheric reactivity, for example, secondary organic aerosol formation. $^{3-6}$

Ethanol was first introduced as a commercial alternative to fossil fuels in Brazil in the early 1980s and its use has strongly increased since the 2000s. For a decade now a generation of cars termed flexible fuel vehicles (FFV) has allowed the use of any content of anhydrous ethanol from 27\% (mixed with gasoline, E27) to pure hydrous ethanol (E100). Both fuels (E27 and E100) are available at the petrol station and the consumer can choose whether to use E27 or E100, or combine them to reach an intermediate ethanol fraction (E50 or E90, for example). ${ }^{6}$ Most of motorcycles are not flexible fuel vehicles, and thus can only be fueled by E27. Heavy-duty vehicles are fueled by diesel with 7\% biodiesel (B7). During the period of our study (austral summer 2013), the state of São Paulo consumed on total $10 \%$ more ethanol than gasoline, namely $6.98 \times 10^{5} \mathrm{~m}^{3}$ of ethanol versus $6.35 \times 10^{5} \mathrm{~m}^{3}$ of gasoline per month.

Received: July 7, 2015

Revised: September 10, 2015

Accepted: September 14, 2015

Published: September 14, 2015 


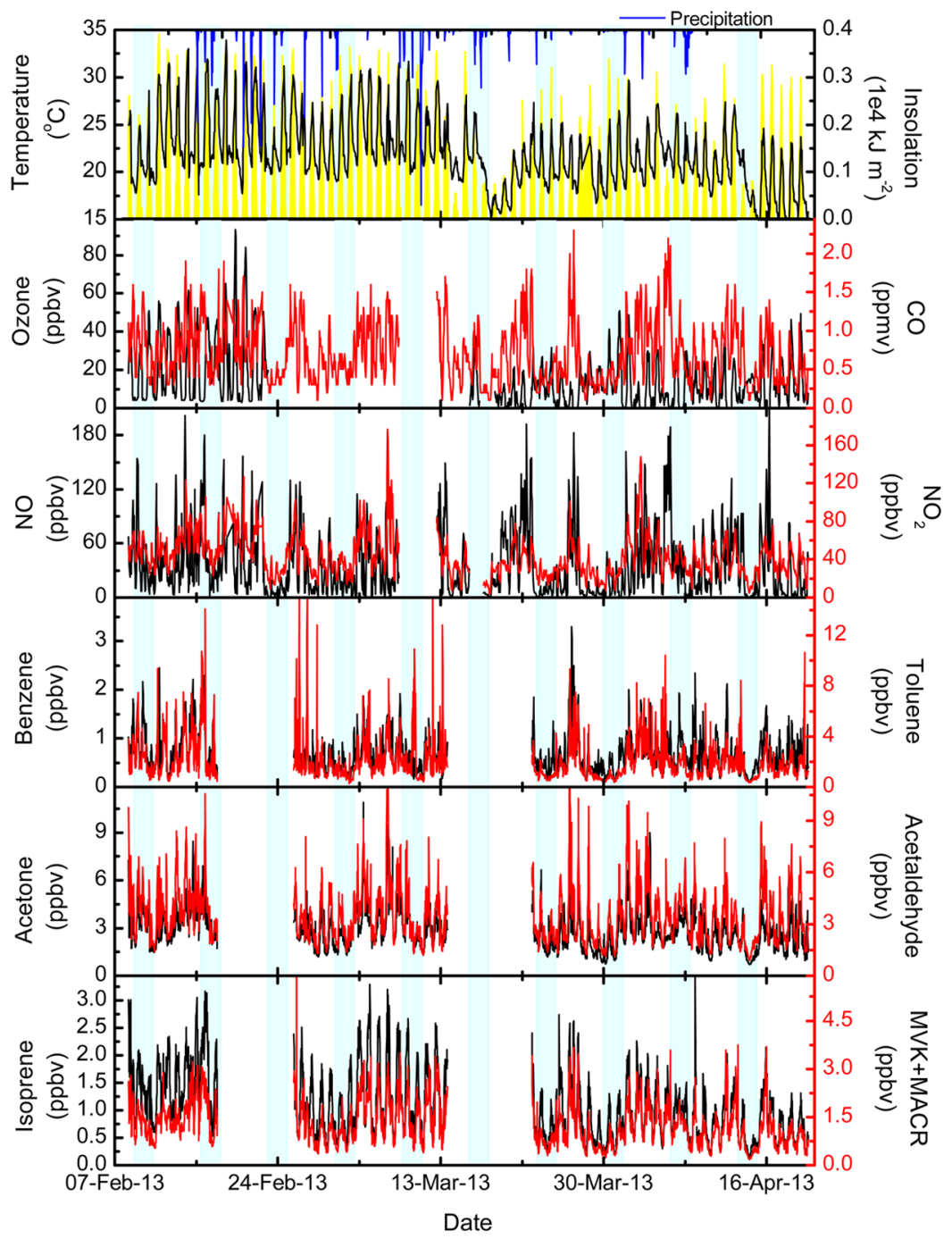

Figure 1. Time series of meteorological parameters and ambient mixing ratios of several species. Weekends are marked in light blue. Ozone, CO, $\mathrm{NO}$, and $\mathrm{NO}_{2}$ data were provided by the São Paulo State Environmental Agency, station Cerqueira César.

Aiming to better assess the role of vehicular emissions in the SPMA, a comprehensive project entitled FONTES ("sources" in Portuguese) was carried out. The project encompasses vehicular exhaust emissions characterization using standard dynamometer test cycles, tunnel $^{1}$ and ambient measurements, ${ }^{8}$ as well as numerical modeling. Ambient measurements were largely based on filter collection (over 1200 filters collected at four sites). Furthermore, intensive campaigns were performed using a suite of real-time instrumentation, including instrumentation for aerosol and gas-phase characterization. For several of these instruments, this was the first deployment in such unique environment.

Among the innovative aspects of the FONTES ambient measurements, we include real-time measurements of a suite of volatile organic compounds (VOCs), including oxygenated VOCs (OVOCs). VOCs serve as fuel for the photochemical production of ozone, ${ }^{9}$ influence the oxidizing capacity of the atmosphere $^{10}$ and have been increasingly identified to contribute to the aerosol burden of the atmosphere. ${ }^{11-13}$ In urban areas, VOC emissions are dominated by anthropogenic sources and, as such, their quantification is a first critical step to develop effective abatement strategies, as well as determine their environmental impacts.
Previous laboratory studies have shown a significant change in the emission profile with varying levels of ethanol content in gasoline. ${ }^{14-16}$ Acetaldehyde, for example, is an important OVOC with well-known impact on human health ${ }^{17}$ and ozone formation. ${ }^{9}$ Acetaldehyde was observed to increase with increasing ethanol usage. ${ }^{18}$ Benzene, also a VOC with important effects on human health ${ }^{19}$ and a relevant aerosol precursor, $^{20}$ showed the opposite trend, that is, emission reduction with increasing ethanol content in gasoline. ${ }^{21}$ The objective of this study is to provide the quantification of a suite of $(\mathrm{O}) \mathrm{VOCs}$ in a megacity largely impacted by biofuel use, and furthermore, to assess under real-world conditions their anthropogenic emission ratios. The observed VOC emission ratios will then be compared with observations in megacities worldwide, seeking to identify trends in the VOC emission profile linked to the extensive biofuel use.

\section{MATERIALS AND METHODS}

The measurements described here were carried out from 08 February to 23 April 2013 at a sampling site in downtown São Paulo, surrounded by $12-35 \mathrm{~km}$ of dense urban occupation. The site is located at the Public Health Faculty $\left(23^{\circ} 33^{\prime} 13.87^{\prime \prime} \mathrm{S}\right.$ $\left.46^{\circ} 40^{\prime} 23.46^{\prime \prime} \mathrm{W}\right)$, at the crossing of Dr. Arnaldo and Teodoro 
Sampaio avenues, one of the most heavily impacted areas by traffic emissions within the SPMA. ${ }^{22}$

A quadrupole Proton-Transfer-Reaction Mass Spectrometer (PTR-MS, Ionicon Analytic, Austria) was used to provide realtime VOC mixing ratios. The system was operated under standard conditions $(2.2 \mathrm{mbar}$ drift tube pressure, $600 \mathrm{~V}$ drift voltage, E/N $140 \mathrm{Td}$ ). Every $60 \mathrm{~min}$ air was diverted through a catalytic converter (Supelco, Inc. with platinum pellets heated to $400{ }^{\circ} \mathrm{C}$ ) to assess the background signal for each species. A system calibration was performed during the campaign using permeation tubes stabilized at $40{ }^{\circ} \mathrm{C}$ for isoprene, benzene, toluene, and $p$-xylene. ${ }^{23,24}$ Furthermore, methanol, acetaldehyde, acetone, isoprene, MVK+MACR, MEK, benzene, toluene and $p$-xylene were postcampaign calibrated using a set of gravimetrically prepared multicomponent mixtures (Apel Riemer Inc., USA) for a large range of humidity values. Concentration estimates of compounds calibrated by both methods agreed well within instrumental accuracy. ${ }^{25}$ The PTRMS was deployed on the third floor of the Public Health Faculty building, roughly $15 \mathrm{~m}$ above street level. Air was sampled through an unheated $5 \mathrm{~m}$ long $1 / 8 \mathrm{in}$. O.D. PTFE tube to the sampling system.

The instrument detection limit (DL) was calculated according to Taipale et al. (2008), i.e., calculated as two sigma of the baseline corrected background signal. The species reported here are methanol $(\mathrm{m} / z 33$ - DL 314 pptv), acetaldehyde $(\mathrm{m} / z 45$ - DL $179 \mathrm{pptv})$, acetone $(\mathrm{m} / z 59-\mathrm{DL}$ $40 \mathrm{pptv})$, isoprene $(\mathrm{m} / z 69$ - DL $38 \mathrm{pptv}), \operatorname{MVK}+\operatorname{MACR}(\mathrm{m} / z$ 71 - DL 19 pptv), MEK ( $m / z 73$ - DL 20 pptv), benzene $(m / z$ 79 - DL $14 \mathrm{pptv})$, toluene $(\mathrm{m} / z 93$ - DL $27 \mathrm{pptv})$ and C8aromatics $(\mathrm{m} / z 107$ - DL $28 \mathrm{pptv})$.

Although the PTR-MS technique allows for real-time measurement of VOCs down to very low mixing ratios, its species separation is solely based on the compound molecular mass, which results in limited speciation capability. ${ }^{25}$ Therefore, interference from other species cannot be completely ruled out, in particular for acetone and isoprene, which have previously been reported to suffer interferences in urban areas. ${ }^{25,27}$ Acetone has been previously identified to suffer an interference from propanal, however under a large set of environments the contribution of the former was limited to $10 \% .^{25}$ Isoprene has been observed to suffer from interferences from furans and cycloalkanes. Whereas the former is only significantly emitted from biomass burning, ${ }^{25}$ the latter can be significant under ambient environments. ${ }^{27}$

The data for ozone $\left(\mathrm{O}_{3}\right)$, nitric oxide (NO), nitrogen dioxide $\left(\mathrm{NO}_{2}\right), \mathrm{NO}_{x}\left(\mathrm{NO}+\mathrm{NO}_{2}\right)$, and carbon monoxide (CO) reported here was provided by the São Paulo State Environmental Agency (CETESB), from the Cerqueira César station, some $50 \mathrm{~m}$ from the sampling site.

\section{RESULTS AND DISCUSSION}

Time Series and Meteorology. The campaign took place during a southern hemisphere summer/fall, with an average temperature of $21.9 \pm 3.6{ }^{\circ} \mathrm{C}$ and average humidity of $76 \pm$ $15 \%$ (Figure 1). Close to $80 \%$ of the days were considered sunny $\left(24 \mathrm{~h}\right.$ integrated insolation $\left.>10000 \mathrm{~kJ} \mathrm{~m}^{-2}\right)$. Mean mixing ratios of the monitored species are depicted in Table 1. The observed values of $\mathrm{CO}, \mathrm{NO}_{x}$ and ozone are comparable with observed values in other megacities such as Mexico City, ${ }^{28}$ Paris, ${ }^{29}$ Houston $^{30}$ and New York, ${ }^{31}$ under comparable meteorological conditions. It is interesting to notice that observed ozone values are significantly lower at the sampling
Table 1. Mean Mixing Ratios Observed during the Campaign, Numbers Are Given in ppbv

\begin{tabular}{lcc}
\multicolumn{1}{c}{ parameter } & mean & std \\
ozone & 14.0 & 12.8 \\
ozone $_{12: 00-18: 00}$ & 25.8 & 14.0 \\
$\mathrm{CO}$ & 702 & 389 \\
$\mathrm{NO}$ & 35.4 & 36.9 \\
$\mathrm{NO}_{2}$ & 43.1 & 21.3 \\
$\mathrm{NO}_{x}$ & 78.5 & 50.1 \\
methanol & 4.37 & 1.57 \\
acetaldehyde & 3.42 & 1.98 \\
acetone & 2.82 & 1.31 \\
isoprene & 1.06 & 0.68 \\
MVK+MACR & 1.26 & 0.77 \\
MEK & 1.09 & 1.01 \\
benzene & 0.67 & 0.44 \\
toluene & 2.11 & 2.06 \\
C8 aromatics & 1.52 & 1.47
\end{tabular}

site, in a downtown area, than usually found in the SPMA (40$70 \mathrm{ppbv}){ }^{6}$ This difference is mainly attributed to the abundance of $\mathrm{NO}_{x}$ from vehicular sources, and as such a reduction of ozone is expected in a VOC-limited regime. ${ }^{6}$

The diurnal pattern of $\mathrm{CO}$ and $\mathrm{NO}$ (as well as $\mathrm{NO}_{x}$ ) present a distinct peak in the morning rush hour consistent with a dominant vehicular source (Figure 2). Ozone levels are

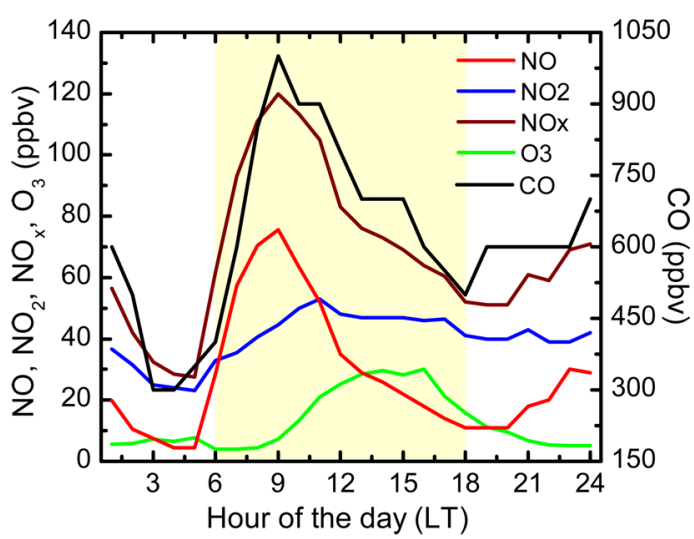

Figure 2. Diurnal profile of $\mathrm{CO}, \mathrm{NO}, \mathrm{NO}_{2}, \mathrm{NO}_{x}$, and ozone from the Cerqueira César site during the time of the campaign.

observed to increase around 09:00 and reach a plateau around noon until 16:00. Diurnal patterns of $\mathrm{NO}_{x}$ and $\mathrm{CO}$ show a similar behavior, suggesting a homogeneous source profile throughout the day. Furthermore, the average $\mathrm{NO}_{x} / \mathrm{CO}$ ratio $(0.11 \pm 0.03)$ is comparable with values seen for light-duty vehicles recently derived from tunnel measurements (0.049 \pm $0.05)$, but is much lower than rates seen for heavy-duty vehicles $(2.4 \pm 1.6) .^{32}$

The wind pattern during the campaign is shown in Figure 3, depicting a predominance of easterly winds during the morning and night hours, and well-defined NW and SE components in the afternoon. Whereas the sampling site is largely impacted by vehicular sources from all directions, biogenic VOCs (BVOCs) are likely to originate from Ibirapuera Park. Comprising an area of $1.5 \mathrm{~km}^{2}$ and over 15000 tress, the park is located $4 \mathrm{~km}$ southeast of the sampling site. Such wind direction is dominant in the afternoon and shall be considered when interpreting the partitioning of primary anthropogenic or biogenic/secondary 

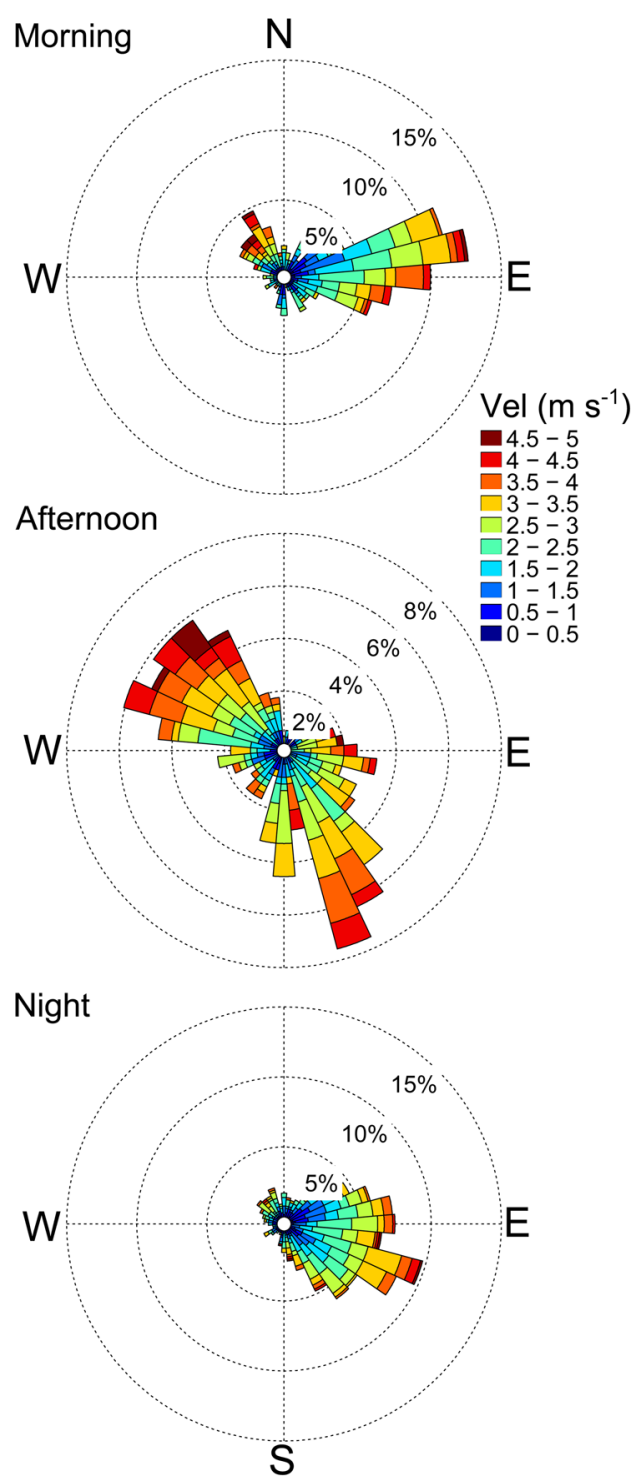

Figure 3. Wind rose during the sampling period. Morning hours range from 06:00-12:00, afternoon hours range from 12:00-18:00 and night hours from 18:00-06:00. Data from the National Institute of Meteorology.

components of VOCs in the corresponding Section. No significant changes are observed in average wind velocities in the morning $\left(1.6 \pm 1.3 \mathrm{~m} \mathrm{~s}^{-1}\right)$, afternoon $\left(2.4 \pm 1.2 \mathrm{~m} \mathrm{~s}^{-1}\right)$ or nighttime $\left(1.5 \pm 1.2 \mathrm{~m} \mathrm{~s}^{-1}\right)$ hours.

Emission Ratios. Real-time measurement of ambient VOCs provides a powerful data set for quantification of urban emission factors, although photochemical processing and dilution/mixing must be accounted for. The latter is considered via the normalization of a given VOC by a long-lived anthropogenic marker, usually $\mathrm{CO}$ or acetylene. Photochemical processing can be corrected by an estimation of the plume age and estimated reaction rates. ${ }^{33}$ However, the sampling station is found within the SPMA, and thus plume age is considered highly uncertain. Another approach recently developed ${ }^{34}$ relies on applying a linear regression fit to calculate the slope of the scatterplot of nighttime data (20:00-06:00 local time) between a given VOC and CO. During the nighttime, atmospheric processing of most VOCs can be considered negligible and, furthermore, the emission ratios of VOCs associated with plant emissions during photosynthesis, such as isoprene, are carried out in the absence of light. ${ }^{34}$

Interestingly, during the nighttime most of the VOCs have correlated well with $\mathrm{CO}\left(R^{2}>0.8\right)$, including those usually associated with biogenic emissions and/or secondary formation, such as acetone, acetaldehyde and MVK+MACR (Figure S1). Such a high correlation indicates that such VOCs share a common source with CO (e.g., combustion) in regard to evaporation, for example. The correlation of MEK with $\mathrm{CO}$ is an exception $\left(R^{2} \approx 0.5\right)$, possibly due to varying degrees of biogenic contributions during night hours of such long-lived species. ${ }^{35}$ Curiously, toluene also yielded a moderately good correlation $\left(R^{2}=0.65\right)$, which can indicate whether some impact of evaporation, which is independent of $\mathrm{CO}$, or the result of heterogeneity on emission ratios emissions throughout the campaign for this particular compound.

The observed emission ratios are found in close agreement with other megacities (Table 2), despite the specificity of the

Table 2. Urban Emission Ratios of VOCs Given in pptv/ ppbv CO

\begin{tabular}{|c|c|c|c|c|c|c|}
\hline VOC & $\begin{array}{c}\text { São } \\
\text { Paulo }\end{array}$ & $\begin{array}{c}\text { Los } \\
\text { Angeles }^{a}\end{array}$ & Paris $^{a}$ & $\begin{array}{c}\text { Mexico } \\
\text { City }^{b}\end{array}$ & London $^{c}$ & $\begin{array}{c}\text { US } \\
\text { Cities }^{d}\end{array}$ \\
\hline methanol & 5.39 & 21.72 & & 2.1 & - & \\
\hline acetaldehyde & 3.93 & 5.42 & & 1.0 & 4.14 & \\
\hline acetone & 3.59 & 11.78 & & 0.51 & 3.18 & \\
\hline isoprene & 1.17 & 0.30 & & $0.08^{e}$ & 1.13 & \\
\hline $\mathrm{MVK}+\mathrm{MACR}$ & 1.63 & 0.36 & & & & \\
\hline MEK & 1.42 & & & 0.29 & & \\
\hline benzene & 1.03 & 1.30 & 1.07 & 1.21 & 1.59 & 0.70 \\
\hline toluene & 3.10 & 3.18 & 12.30 & 4.2 & 3.09 & 2.70 \\
\hline C8 aromatics & 2.15 & 2.45 & 4.75 & 4.3 & 3.69 & 1.40 \\
\hline
\end{tabular}

Brazilian fuel. Acetaldehyde, for example, which could be expected to have a significantly high emission ratio due to the ethanol content in gasoline, ${ }^{18}$ had a calculated emission ratio of $3.93 \mathrm{pptv} / \mathrm{ppbv} \mathrm{CO}$, whereas in Los Angeles the emission ratio is $5.42 \mathrm{pptv} / \mathrm{ppbv} \mathrm{CO}^{34}$ and in Mexico City $1.0 \mathrm{pptv} / \mathrm{ppbv}$ $\mathrm{CO} .{ }^{36}$ Benzene, on the contrary, has been reported to decrease with increasing ethanol usage, ${ }^{21}$ had a higher emission ratio (1.03 pptv/ppbv) than the average of 28 U.S. cities ( $0.70 \mathrm{pptv} /$ ppbv $\left.\mathrm{CO}^{37}\right)$, but a lower emission ratio than Los Angeles (1.30 pptv/ppbv $\mathrm{CO}^{34}$ ), Paris (1.07 pptv/pppbv $\mathrm{CO}^{34}$ ) and Mexico City $\left(1.21 \mathrm{pptv} / \mathrm{ppbv} \mathrm{CO}^{36}\right)$. Interestingly, at high fuel distillation temperatures, benzene emission has also been reported to increase with increasing ethanol content. ${ }^{14}$

A relatively high emission ratio of anthropogenic isoprene has been observed, yielding a ratio of $1.17 \mathrm{pptv} / \mathrm{ppbv} \mathrm{CO}$. The emission ratios of anthropogenic isoprene for Los Angeles were

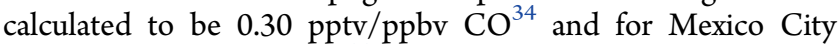
were $0.08 \mathrm{pptv} / \mathrm{ppbv} \mathrm{CO},{ }^{38}$ respectively. Such a high emission ratio derived here could be the result of interference of other species, such as cycloalkanes, as previously discussed, and certainly motivates further studies.

The lack of a well-defined trend in the VOC emission profile in São Paulo in regard to other megacities indicates that driving conditions and fleet composition play a more important role than the ethanol content in gasoline. Large scale studies in São Paulo, including events of abrupt changes in the ethanol 


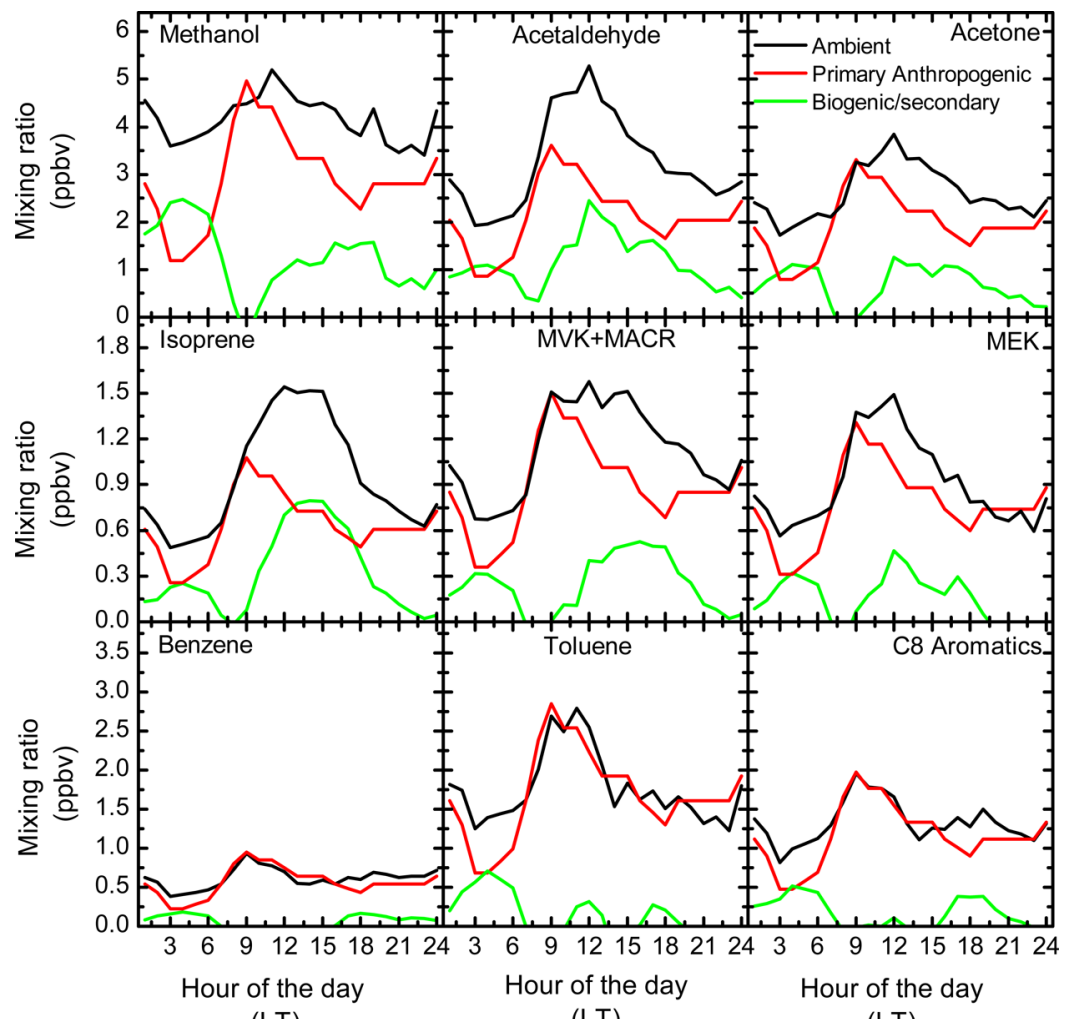

(LT)

(LT)

(LT)

Figure 4. Diurnal profile of the mixing ratios of the monitored VOCs, the component apportioned to primary anthropogenic (PA) and the biogenic/ secondary component.

consumption, ${ }^{6}$ will certainly aid in elucidating the effects of biofuel under real-world conditions.

Biogenic/Secondary Components. By using the nighttime derived emission ratios to the entire $\mathrm{CO}$ data set (including daytime), one can estimate in a simple way the primary anthropogenic component of the studied VOCs eq 1:

$$
\mathrm{PA}=\mathrm{ER} \times \mathrm{CO}
$$

Where PA is the primary anthropogenic component of a given VOC and ER is the emission ratio. By extending such an equation to daytime, two ground assumptions are made: (i) the fleet composition is comparable between daytime and nighttime (i.e., same ER) and (ii) the anthropogenic component of the VOCs is dominated by local emissions, with little reaction time in the atmosphere. Argument (i) is supported through $\mathrm{CO} / \mathrm{NO}_{x}$ analysis, indicating comparable values from daytime and nighttime. Argument (ii) arises from knowledge of local traffic, and will be supported by results presented below.

The difference between the PA and actual ambient mixing ratios, i.e., the "excess", is then considered the contribution of other sources to the analyzed VOCs. Such sources are thought in this case to be mainly dominated by biogenic sources or secondarily formed in the atmosphere:

$$
\text { biogenic/secondary }=\mathrm{VMR}-\mathrm{PA}
$$

Where VMR is the volume mixing ratio of a given VOC. The diurnal pattern of VMR, PA, and the biogenic/secondary component is depicted in Figure 4.

The ambient mixing ratios of benzene, toluene, and C8 aromatics are almost entirely apportioned to the PA component. The fact that daytime concentrations of these compounds can be explained by the nighttime derived ER multiplied by daytime $\mathrm{CO}$ mixing ratio allows us to conclude that for this particular site: (i) There is a homogeneous source profile throughout the day, as already indicated by a relatively constant $\mathrm{CO} / \mathrm{NO}_{x}$ ratio; (ii) Fuel evaporation of the studied species is negligible; (iii) Reaction time in the atmosphere can also be considered negligible.

Other species besides aromatics have shown a more significant contribution of the biogenic/secondary component. Furthermore, isoprene, acetaldehyde and, to a less extent, acetone, have depicted peaks of biogenic/secondary component in the afternoon of comparable magnitude to the PA component morning peak. It is important to notice that local winds in the afternoon suggest transport from Ibirapuera Park, a large source of BVOCs within SPMA, as previously discussed. Interestingly, the biogenic/secondary component of isoprene and MVK+MACR depict a well-defined mid-day peak characteristic of plant emissions, ${ }^{39}$ however with comparable magnitude between them ( $0.8 \mathrm{ppbv}$ for the former and 0.6 ppbv for the latter) suggesting a relatively processed air mass. ${ }^{40}$

Many of the BVOCs emissions are associated with photosynthesis, which in turn are directly or indirectly linked to ambient temperature. ${ }^{39}$ Therefore, the biogenic/secondary component can be further analyzed considering its variation with daytime ambient temperature. As shown in Figure 5, only isoprene $\left(R^{2}=0.40\right)$ and MVK+MACR $\left(R^{2}=0.31\right)$ depict some correlation with temperature, indicating that these are the only species studied here which are directly linked with biogenic emissions. The temperature dependence for the biogenic component of isoprene and MVK+MACR is $101 \pm$ 6 pptv $\mathrm{K}^{-1}$ and $80 \pm 5$ pptv $\mathrm{K}^{-1}$, respectively. While the results shown here provide robust evidence for the nature of species 


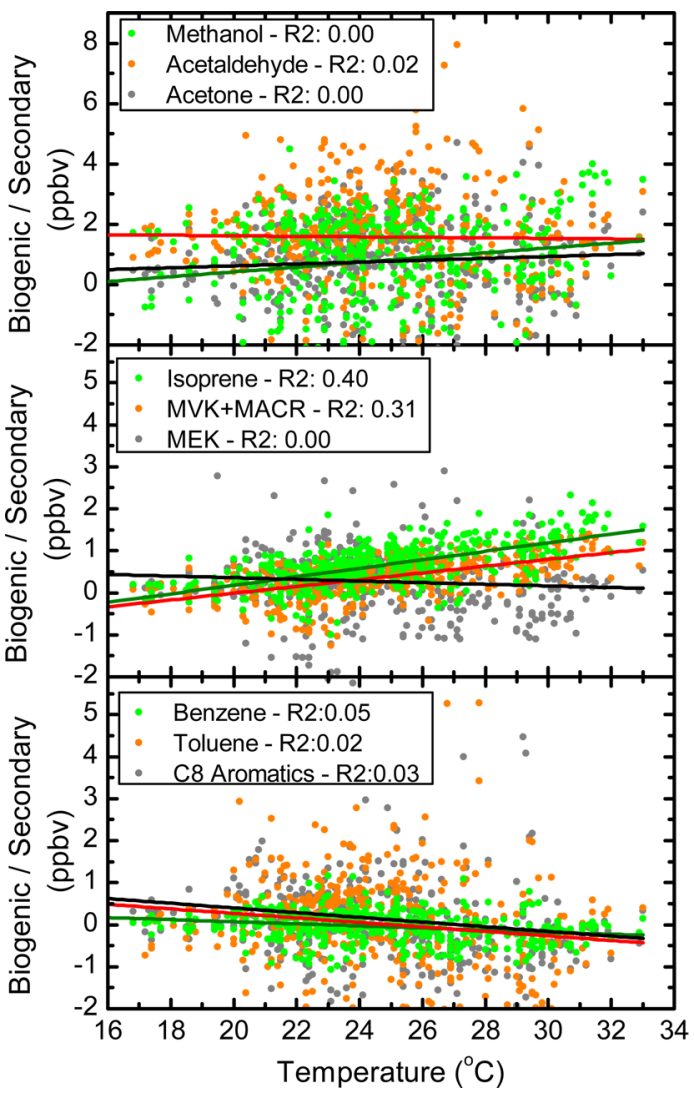

Figure 5. Scatter plot between the biogenic/secondary component and ambient temperature. Values limited from 09:00 to 18:00 (LT).

involved, further studies are required to improve species identification at different locations in such unique atmospheres.

\section{ASSOCIATED CONTENT}

\section{S Supporting Information}

The Supporting Information is available free of charge on the ACS Publications website at DOI: 10.1021/acs.est.5b03281.

Figure S1, Correlation of the given VOC and $\mathrm{CO}$ for the nighttime data (PDF)

\section{AUTHOR INFORMATION}

\section{Corresponding Author}

*Phone: +[55](11) 3091-6925; fax: +[55](11) 3091-6749; email: jbrito@if.usp.br.

\section{Notes}

The authors declare no competing financial interest.

\section{ACKNOWLEDGMENTS}

This work was supported by the Research Foundation of the State of São Paulo (FAPESP, process 2013/25058-1), by the National Council for Scientific and Technological Development (CNPq) and PETROBRAS (project 6000.006831.11.9). We acknowledge Nelson Alves and Gisele Birman Tonietto for the PETROBRAS coordination and Dr. Carsten Warneke for the scientific discussion. We thank the support from Prof. Pérola Vasconcellos in calibrating the system. We thank Ana Lúcia Loureiro, Alcides Ribeiro, Fernando Morais and Fábio Jorge for their valuable support before and during the campaigns. We thank the support from the School of Public Health staff that made the campaign possible. We gratefully acknowledge the
São Paulo State Environmental Agency (CETESB) for providing $\mathrm{NO}_{x}, \mathrm{CO}$ and ozone data.

\section{REFERENCES}

(1) Brito, J.; Rizzo, L. V.; Herckes, P.; Vasconcellos, P. C.; Caumo, S. E. S.; Fornaro, a.; Ynoue, R. Y.; Artaxo, P.; Andrade, M. F. Physicalchemical characterisation of the particulate matter inside two road tunnels in the São Paulo Metropolitan Area. Atmos. Chem. Phys. 2013, 13, 12199-12213.

(2) Sao Paulo State Environmental Agency - CETESB. Annual Report of Air Quality in the Sao Paulo State, 2014.

(3) de Abrantes, R.; De Assunção, J. a. V.; Pesquero, C. R.; Bruns, R. E.; Nóbrega, R. P. Emission of polycyclic aromatic hydrocarbons from gasohol and ethanol vehicles. Atmos. Environ. 2009, 43, 648-654.

(4) Ferreira da Silva, M.; de Assunção, J. a. V.; de Fátima Andrade, M.; Pesquero, C. R. Characterization of metal and trace element contents of particulate matter (PM10) emitted by vehicles running on Brazilian fuels-hydrated ethanol and gasoline with $22 \%$ of anhydrous ethanol. J. Toxicol. Environ. Health, Part A 2010, 73, 901-909.

(5) Kirstine, W. V.; Galbally, I. E. The global atmospheric budget of ethanol revisited. Atmos. Chem. Phys. 2012, 12, 545-555.

(6) Salvo, A.; Geiger, F. M. Reduction in local ozone levels in urban São Paulo due to a shift from ethanol to gasoline use. Nat. Geosci. 2014, 7, 450-458.

(7) Brazilian National Agency of Petroleum Natural Gas and Biofuels. Oil, Natural Gas and Biofuels Statistical Yearbook, 2014.

(8) Almeida, G. P.; Brito, J.; Morales, C. a.; Andrade, M. F.; Artaxo, P. Measured and modelled cloud condensation nuclei (CCN) concentration in São Paulo, Brazil: The importance of aerosol size-resolved chemical composition on $\mathrm{CCN}$ concentration prediction. Atmos. Chem. Phys. 2014, 14, 7559-7572.

(9) Atkinson, R. Atmospheric chemistry of VOCs and NOx. Atmos. Environ. 2000, 34, 2063-2101.

(10) Singh, H. B.; Kanakidou, M.; Crutzen, P. J.; Jacob, D. J. High concentrations and photochemical fate of oxygenated hydrocarbons in the global troposphere. Nature 1995, 378, 50-54.

(11) Allan, J. D.; Morgan, W. T.; Darbyshire, E.; Flynn, M. J.; Williams, P. I.; Oram, D. E.; Artaxo, P.; Brito, J.; Lee, J. D.; Coe, H. Airborne observations of IEPOX-derived isoprene SOA in the Amazon during SAMBBA. Atmos. Chem. Phys. 2014, 14, 11393-11407.

(12) Jimenez, J. L.; et al. Evolution of organic aerosols in the atmosphere. Science (Washington, DC, U. S.) 2009, 326, 1525-9.

(13) $\mathrm{Xu}, \mathrm{L}$;; et al. Effects of anthropogenic emissions on aerosol formation from isoprene and monoterpenes in the southeastern United States. Proc. Natl. Acad. Sci. U. S. A. 2015, 112, 37-42.

(14) Durbin, T. D.; Miller, J. W.; Younglove, T.; Huai, T.; Cocker, K. Effects of fuel ethanol content and volatility on regulated and unregulated exhaust emissions for the latest technology gasoline vehicles. Environ. Sci. Technol. 2007, 41, 4059-4064.

(15) Hochhauser, A. M.; Schleyer, C. H. Summary of Research on the Use of Intermediate Ethanol Blends in On-Road Vehicles. Energy Fuels 2014, 28, 3236-3247.

(16) U.S. Environmental Protection Agency. Assessing the Effect of Five Gasoline Properties on Exhaust Emissions from Light Duty Vehicles Certified to Tier 2 Standards: Final Report on Program Design and Data Collection , (EPAct/V2/E-89, EPA-420-R-13-004), 2013.

(17) Woutersen, R.; Appelman, L.; Garderen-Hoetmer, A. V.; Feron, V. Inhalation toxicity of acetaldehyde in rats. III. Carcinogenicity study. Toxicology 1986, 41, 213-231.

(18) Yanowitz, J.; Knoll, K.; Kemper, J.; Luecke, J.; McCormick, R. L. Impact of adaptation on flex-fuel vehicle emissions when fueled with E40. Environ. Sci. Technol. 2013, 47, 2990-7.

(19) Dean, B. J. Recent findings on the genetic toxicology of benzene, toluene, xylenes and phenols. Mutat. Res., Rev. Genet. Toxicol. 1985, 154, 153-181.

(20) Li, K.; Wang, W.; Ge, M.; Li, J.; Wang, D. Optical properties of secondary organic aerosols generated by photooxidation of aromatic hydrocarbons. Sci. Rep. 2014, 4.10.1038/srep04922 
(21) Tessum, C. W.; Marshall, J. D.; Hill, J. D. A spatially and temporally explicit life cycle inventory of air pollutants from gasoline and ethanol in the United States. Environ. Sci. Technol. 2012, 46, $11408-17$.

(22) CETESB, CETESB annual report; 2013.

(23) Brito, J.; Zahn, A. An unheated permeation device for calibrating atmospheric VOC measurements. Atmos. Meas. Tech. 2011, 4, $2143-$ 2152

(24) Jost, C. Calibration with permeation devices: is there a pressure dependence of the permeation rates? Atmos. Environ. 2004, 38, 35353538 .

(25) de Gouw, J.; Warneke, C. Measurements of volatile organic compounds in the earth's atmosphere using proton-transfer-reaction mass spectrometry. Mass Spectrom. Rev. 2007, 26, 223-57.

(26) Taipale, R; Ruuskanen, T. M.; Rinne, J.; Kajos, M. K.; Hakola, H.; Pohja, T.; Kulmala, M. Technical Note: Quantitative long-term measurements of VOC concentrations by PTR-MS; measurement, calibration, and volume mixing ratio calculation methods. Atmos. Chem. Phys. 2008, 8, 6681-6698.

(27) Valach, a. C.; Langford, B.; Nemitz, E.; MacKenzie, a. R.; Hewitt, C. N. Concentrations of selected volatile organic compounds at kerbside and background sites in central London. Atmos. Environ. 2014, 95, 456-467.

(28) Shirley, T. R.; Brune, W. H.; Ren, X.; Mao, J.; Lesher, R.; Cardenas, B.; Volkamer, R.; Molina, L. T.; Molina, M. J.; Lamb, B.; Velasco, E.; Jobson, T.; Alexander, M. Atmospheric oxidation in the Mexico City Metropolitan Area (MCMA) during April 2003. Atmos. Chem. Phys. 2006, 6, 2753-2765.

(29) Zhang, Q. J.; et al. Formation of organic aerosol in the Paris region during the MEGAPOLI summer campaign: evaluation of the volatility-basis-set approach within the CHIMERE model. Atmos. Chem. Phys. 2013, 13, 5767-5790.

(30) Mao, J.; Ren, X.; Chen, S.; Brune, W. H.; Chen, Z.; Martinez, M.; Harder, H.; Lefer, B.; Rappengluck, B.; Flynn, J.; Leuchner, M. Atmospheric oxidation capacity in the summer of Houston 2006: Comparison with summer measurements in other metropolitan studies. Atmos. Environ. 2010, 44, 4107-4115.

(31) Ren, X.; Harder, H.; Martinez, M.; Lesher, R. L.; Oliger, A.; Shirley, T.; Adams, J.; Simpas, J. B.; Brune, W. H. $\{\mathrm{HOx}\}$ concentrations and $\{\mathrm{OH}\}$ reactivity observations in New York City during PMTACS-NY2001. Atmos. Environ. 2003, 37, 3627-3637.

(32) Pérez-Martínez, P.; Miranda, R.; Nogueira, T.; Guardani, M.; Fornaro, A.; Ynoue, R.; Andrade, M. Emission factors of air pollutants from vehicles measured inside road tunnels in São Paulo: case study comparison. Int. J. Environ. Sci. Technol. 2014, 11, 2155-2168.

(33) Warneke, C.; McKeen, S. A.; de Gouw, J. A.; Goldan, P. D.; Kuster, W. C.; Holloway, J. S.; Williams, E. J.; Lerner, B. M.; Parrish, D. D.; Trainer, M.; Fehsenfeld, F. C.; Kato, S.; Atlas, E. L.; Baker, A.; Blake, D. R. Determination of urban volatile organic compound emission ratios and comparison with an emissions database. J. Geophys. Res. 2007, 112, D10S47.

(34) Borbon, A.; et al. Emission ratios of anthropogenic volatile organic compounds in northern mid-latitude megacities: Observations versus emission inventories in Los Angeles and Paris. Journal of Geophysical Research: Atmospheres 2013, 118, 2041-2057.

(35) Chew, A. A.; Atkinson, R. OH radical formation yields from the gas-phase reactions of $\mathrm{O} 3$ with alkenes and monoterpenes. J. Geophys. Res. 1996, 101, 28649.

(36) Bon, D. M.; et al. Measurements of volatile organic compounds at a suburban ground site (T1) in Mexico City during the MILAGRO 2006 campaign: measurement comparison, emission ratios, and source attribution. Atmos. Chem. Phys. 2011, 11, 2399-2421.

(37) Baker, A. K.; Beyersdorf, A. J.; Doezema, L. a.; Katzenstein, A.; Meinardi, S.; Simpson, I. J.; Blake, D. R.; Sherwood Rowland, F. Measurements of nonmethane hydrocarbons in 28 United States cities. Atmos. Environ. 2008, 42, 170-182.

(38) Apel, E. C.; et al. Chemical evolution of volatile organic compounds in the outflow of the Mexico City Metropolitan area. Atmos. Chem. Phys. 2010, 10, 2353-2375.
(39) Yáñez Serrano, A. M.; Nölscher, A. C.; Williams, J.; Wolff, S.; Alves, E.; Martins, G. A.; Bourtsoukidis, E.; Brito, J.; Jardine, K.; Artaxo, P.; Kesselmeier, J. Diel and seasonal changes of biogenic volatile organic compounds within and above an Amazonian rainforest. Atmos. Chem. Phys. 2015, 15, 3359-3378.

(40) Stroud, C. A.; et al. Isoprene and its oxidation products, methacrolein and methylvinyl ketone, at an urban forested site during the 1999 Southern Oxidants Study. J. Geophys. Res. 2001, 106, 80358046. 